\title{
A házassági névviselés gyakorlata a 21. századi Magyarországon
}

1. A házassági névviselés jogi háttere. Az állami anyakönyvezésről szóló 1894. évi törvény szabályozta először hivatalosan a névviselést és vele a nők házasságkötés utáni névviselési lehetőségeit. Ez az 1894. évi XXXIII. törvény 1895. október 1-jétől 1952. december 31-ig volt hatályban. A fenti törvény értelmében ekkor mindössze egyetlen névformát engedélyeztek a házasságra lépő nőknek: Zrínyi Ilona és Rákóczi Ferenc házassága esetén Zrínyi Iloná-ból csak Rákóczi Ferencné lehetett (UGróczKy1997: 12). A házasságról, a családról és a gyámságról szóló 1952. évi IV. törvénnyel (Családjogi törvény = Csjt.) egy időben hatályba lépett az anyakönyvekről szóló 1952. évi 19. tv. Ez a családjogi törvény a férjes asszonyoknak már a Rákóczi Ferencné Zrínyi Ilona és a Zrínyi Ilona alakok használatát is engedélyezi. A Csjt. 1974-es módosítása a felmerülő társadalmi igények nyomán újabb két lehetőséggel bővítette a kínálatot: a gyorsan népszerüvé váló Rákócziné Zrínyi Ilona névtípussal és a sokak számára idegen mintát sejtető Rákóczi Ilona alakkal.

A következő változtatás a 2002-es szabályozás volt (FARKAS 2003: 136). Az európai minták követésének igénye, Magyarország 2004-es európai uniós csatlakozása is hozzájárult a törvénymódosítás előkészítéséhez, hiszen a két családnév összekapcsolásával létrehozott, kötőjeles típusú házassági név használata számos uniós országban régóta bevett gyakorlatnak számít, melynek átvétele felgyorsult a társadalmi változások és az egyenlőségi törekvések hatására (FARKAS 2003: 138; RAÁTz 2004: 66-73, 2007: 169-77; LACZKÓ 2008: 408).

A 2002-es szabályozás célja a házastársak egyenjogúságának biztosítása volt. A szabályozást egy alkotmánybírósági határozat tette szükségessé, amely a férfiak hátrányos megkülönböztetésével járó, ,,alkotmányellenesnek ítélt állapotok megszüntetésére” irányult (FARKAS 2003: 137), mivel az addigi gyakorlat szerint a férfiaknak házasságkötésük alkalmával nem állt módjukban felvenni feleségük nevét, míg a nők számára volt választási lehetőség.

Jelenleg a 2013-as, új Polgári Törvénykönyv (Ptk.) Negyedik könyvének Családjog része, ennek is a IV. fejezet 4:27-4:28. §-a alatt foglaltak biztosítják a házastársak névviselésének jogi hátterét. Ebben a Házastársak névviselése címü rész részletesen kitér a névviselési lehetőségekre. A szabályozás értelmében a leánykori név terminust szükségszerüen felváltotta az összefoglaló jellegü születési név, az asszonynév kifejezést pedig a házassági név megnevezés. A házasságkötésük után a férfiak számára három-, illetve négyféle név használatának lehetőségét biztosítja a törvény: mind a Zrínyi Ferenc, mind a Rákóczi-Zrínyi Ferenc, mind a Zrínyi-Rákóczi Ferenc alak használható, de a házasságra lépő férfi természetesen megtarthatja születési nevét is: Rákóczi Ferenc. E rendelkezések a 2002-es szabályozásban is már megvoltak.

A feleség hat-, illetve hétféle névváltozat közül választhat: így kérheti születési neve megtartását: Zrínyi Ilona, vagy választhatja férje teljes nevét „a házasságra utaló toldással” (ez a -né asszonynévképző hivatalos megnevezése), amelyhez hozzákapcsolhatja a házasságkötés elött közvetlenül viselt nevét, tehát választhatja a Rákóczi Ferencné vagy a Rákóczi Ferencné Zrínyi Ilona alakot is. Továbbá a feleség dönthet amellett is, hogy felveszi a 
férje családi nevét a házasságra utaló toldással, és ehhez a házasságkötés elött közvetlenül viselt nevét hozzákapcsolja: Rákócziné Zrínyi Ilona; vagy a férje családi nevéhez kapcsolja hozzá saját utónevét: Rákóczi Ilona. Továbbá a 2004. január 1-jén életbe lépő 2002-es törvénymódosítás értelmében a mellérendelő kötőjeles megoldások közül is választhatja az egyre divatosabbá váló Rákóczi-Zrínyi Ilona vagy Zrínyi-Rákóczi Ilona alakot. Kérdés, hogy Zrínyi Ilona a fentiek közül melyiket választaná második házassága esetén, amikor ugyanezek a szabályok vonatkoznak a névviselésére, megtoldva azzal a lehetőséggel, hogy akár ,,a házasságkötés előtt közvetlenül viselt nevét”, azaz a közös házassági nevet is viselheti tovább, ha az nem tartalmazta a -né asszonynévképzőt: új házasság esetén a volt feleség a volt férje nevét csak „,a házasságra utaló toldással nem viselheti”, vagyis sem Rákóczi Ferencné, sem Rákóczi Ferencné Zrínyi Ilona, sem Rákócziné Zrinyi Ilona nem maradhat, ha új házasságra lép.

A törvényből az is következik, hogy mind a férj, mind a feleség következő házassága esetén is megőrizheti névviselésében az előző férje/felesége családnevét, ha az nem tartalmazta a „házasságra utaló toldást” (vagyis a -né toldalékot). Így a volt feleség a vonatkozó szabályozás szerint - figyelembe véve a házasságkötés előtt közvetlenül viselt nevét - akár a hosszan kígyózó Thököly Imréné Rákóczi-Zrínyi Ilona avagy Thököly Imréné ZrinyiRákóczi Ilona név mellett is dönthet az új házasság esetén, a volt férj neve pedig RákócziZrinyi Ferenc vagy Zrínyi-Rákóczi Ferenc is maradhatna. A férjek házassági névviselésére vonatkozó szabályozás szerint a második férj is felveheti a felesége teljes családnevét, így ebben a fent bemutatott esetben Thököly Imre akár választhatná a Zrínyi-Rákóczi Imre vagy a Rákóczi-Zrínyi Imre házassági nevet is.

2. Névtípusok: típusnevek? Kutatások a magyar asszonynévhasználat témakörében. Az elmúlt két évtizedben az asszonynévhasználatra vonatkozó legátfogóbb kutatásokat Fercsik Erzsébet végezte (vö. Fercsik 2002, 2008, 2012b, 2013). Ezenkívül többen vizsgálták különböző településeken vagy különböző társadalmi csoportokon belül az aszszonynevek használatát. Az elmúlt évtizedek kutatásait bemutató, a fentiek továbbvezető irodalmát is tartalmazó, átfogó tanulmány szintén FeRCSIK ERzSÉBET munkája (2008), SZILÁGYI-KósA ANIKó jelenkori személynévkutatásról szóló áttekintése pedig a későbbi vizsgálatokra is hivatkozik (2015: 147-148). A témában a legfrissebben BARANYINÉ KócZY JUDIT (2020) végzett kérdőíves kutatást. FARKAS TAMÁs a 20. század második felének magyar asszonynév-változtatásaival foglalkozott (2001: 352-386, l. még 2020), melyek szintén jól tükrözik a társadalmi változások okán kialakult igényeket és azt, hogy ezek nyomán miként módosult törvényesen is a névválasztási lehetőségek köre. E kérvények indoklásaiból is megismerhetjük egy-egy névtípus választásának vélt vagy valós előnyeit és hátrányait, az asszonynévdivat változásának föbb tendenciáit. Ezek révén pedig nyomon követhetök a „női szerep értelmezésének” változásai, melyek az általam kapott további adatközlői válaszokban is visszaköszönnek.

FeRCSIK ERzsÉBET átfogó vizsgálatai során a ma használható házassági neveket a következőképpen csoportosította: tipikus (T), kevésbé tipikus (KT) és nem tipikus (NT) házassági nevekre osztotta a névállományt (FerCsiK 2012a, 2013). A következőkben, kisebb módosítással (l. alább) magam is az általa használt jelöléseket fogom alkalmazni.

„Tipikus házassági neveknek” nevezi azt a csoportot, amelyben „a névből egyértelmüen következtethetünk a családi állapotra" (FERCSIK 2012a: 314). Ilyen nevek (saját példáimnál maradva) a Rákóczi Ferencné, a Rákóczi Ferencné Zrínyi Ilona és a Rákócziné Zrínyi Ilona 
névtípus. Mivel mindháromban megjelenik a -né asszonynévképző, mindegyik utal viselője házas családi állapotára. Míg azonban az első alaknál komoly problémát jelenthet, hogy miként szólítsuk meg viselöjét, hiszen ez a névforma nem tartalmazza az utónevét, addig a másik két forma ugyan hosszabb valamivel, de ezt is feltünteti. FerCsIK nem tesz különbséget a két, tipikus asszonynévnek tartott forma közt: az első (Rákóczi Ferencné) és a második (Rákóczi Ferencné Zrínyi Ilona) alak között, mindkettőt T/1-nek jelöli. Én szerencsésebbnek érzem a $\mathrm{T} / 1 \mathrm{a}$ és a $\mathrm{T} / 1 \mathrm{~b}$ rövidítést, mivel a két névalak közé korántsem tehető egyenlőségjel. A harmadik formát (Rákócziné Zrínyi Ilona) FERCSIK T/2-vel jelöli. Azok a névalakok, amelyekben megjelenik a -né képző, kétségtelenül a leginkább hagyományőrzők; a T/2 forma emellett kompromisszumkereső is, hiszen röviden kifejezi a házas állapotot, de megőrzi az eredeti születési nevet is. Népszerüsége is ennek köszönhető (l. később).

A „kevésbé tipikus házassági nevek” (KT) közé sorolja FerCsIK a kételemü kötőjeles családneveket, melyek esetében „a névből nagy valószínüséggel következtethetünk a családi állapotra": a Zrínyi-Rákóczi Ilona a KT/1, a Rákóczi-Zrínyi Ilona a KT/2 rövidítést kapta (FERCSIK 2012a: 214-18). Használatuk annyiból megtévesztő lehet, hogy ez a névtípus nem kizárólagosan a házassági névviselésre utal, hanem más okokból kötőjellel egymás mellé illesztett családnévalakokat is tartalmazhat. (Erre személyes példával tudok szolgálni: kételemü, kötőjeles születési nevem - Szabó-Törpényi - miatt kérdezősködtek már férjem hogyléte felől úgy, hogy a kötőjeles családnév első eleméhez hozzáillesztették az úr szót, logikusan, de tévesen, mert úgy gondolták, hogy férjem családneve kötőjeles családnevem első eleme.)

A harmadik nagy csoport a „nem tipikus házassági nevek” (NT) csoportja, amelynek legfőbb ismérve, hogy ,a névböl csak előzetes ismeretek birtokában következtethetünk a családi állapotra" (FERCSIK 2013: 375). Ide jellemzően az egy családnevű alakulatokat sorolja FERCSIK: a megőrzött születési nevet NT/1-nek (Zrínyi Ilona), illetve a férj családnevét -né képző nélkül felvevő családnév + utónév típust NT/2-nek (Rákóczi Ilona) jelölve.

A házassági névválasztás kilencvenes évekbeli tendenciáit LACZKó KRISZTINA (2008: 406-412), ezredfordulós trendjeit pedig, a fenti csoportosítást alapul véve, a legátfogóbban szintén FERCSIK ERZSÉBET mutatta be: öt év statisztikai adatait összegezve kimutatta, hogy a kompromisszumos (T/2) névforma népszerüségének fokozatos növekedésével számolhatunk (FERCSIK 2013: 376). Ennek jegyében magam is a jelenlegi tendenciák mögött meghúzódó társadalmi igények motivációs hátterének igyekeztem utánajárni.

3. A házassági névviselés motivációi: identitáskérdések. Az egyén és a közösség kapcsolatában az egyén önmeghatározása szempontjából az identitásnak, vagyis az önazonosság-tudatnak rendkívül fontos szerepe van. Különbséget kell tenni viszont a személyes és a társadalmi identitás fogalma között. Ez utóbbi részét képezik a nemzeti, etnikai, vallási, nemi stb. identitás(ok). Ezeket a kategóriákat a szocializáció folyamatában sajátítja el az egyén, s később „magától értetődőségekként” alkalmazza önmaga és mások társadalmi helyének megállapításakor (CSEPELI 1997: 522). „Kétségtelen, hogy az azonosságtudatnak nincs általános, egységes modellje. Különféle jellegủ identitások vannak, és az identitásnak magának is sokféle, ideológiailag eltérő értelmezése" (PÉNTEK 2011: 31). PATAKI FERENC (1982: 300) szerint az identitás egy közvetítő kategória, amely ,a személyiségnek nevezett konstrukció és a társadalmi struktúra” között helyezkedik el. Az identitás ,az egyén-társadalom viszonyt reflexív módon és szimbolikus formákban építi fel”. 
„A névadásnak, névváltoztatásnak társadalmi, kulturális és lélektani együtthatói vannak" (ZeLLiger 2012: 42), melyeken keresztül szintén alakul, formálódik, kifejeződik az identitás. A névadás a jelenben történik, de a jövőt alakítja. A névválasztással deklaráljuk azonosulásunkat, kifejezhetjük hovatartozás-érzésünket, identitásunkat.

A házassági név is fontos önazonosság-jelölő, identitáskifejező funkcióval bír, akár hagyományos, akár a fentebbi értelemben vett kompromisszumos házassági nevet választanak a házasságra lépők, akár pedig a születési nevük megőrzése mellett döntenek. Erről tanúskodnak a 2017 januárjában végzett kérdőíves felmérésem eredményei is. A mintavétel korántsem tekinthető reprezentatívnak, azonban a visszatérő válaszmotívumokból egyértelmüen kirajzolódnak a névválasztás motivációinak fő tendenciái, az egyes névtípusok esetében egymás ellenében ható összetevők. Ezek a tartalomelemzéssel feldolgozott gyakorisági komponensek a hagyományosnak tekinthető asszonynévformák által legjobban motivált összetartozás kifejezésének igényétől az individuum egyedi önkifejezésének igényéig terjedő skálán mozognak, amelynek középső részén a kevésbé tipikus nevek helyezkednek el. A válaszmotívumok háttere rendkívül összetett, sokdimenziós, mely a családi hagyományok, a társadalmi elvárások, valamint a munkaerőpiaci lehetőségek és a névdivat pszichoszociológiai kérdéskörét is érinti. (A válaszokban a személyiségi jogok védelmében átírom a családneveket az általam használt Zrínyi, Rákóczi példákra, illetve ha az adatközlői válasz tartalmazta a nevet, akkor csak a kezdőbetűt közlöm belőle.)

A hetvenfös mintavétel legfontosabb kiválasztási kritériuma az volt, hogy minden adatközlője olyan legyen, aki 2004 után kötött házasságot. Így lehetőségem volt a ma választható összes névtípus motiváltságának vizsgálatára és a napjainkban zajló aktuális névválasztási kérdések elemzésére. A válaszadók mindegyike felsőfokú végzettségü, és Budapesten vagy nagyobb magyarországi városban él, emiatt az alacsonyabb iskolai végzettségüek és kisebb településen élők névválasztási motivációját nem tudtam vizsgálni. Éppen ezért a névtípusok gyakoriságának előfordulása csak a 20-40 év közötti nagyvárosi értelmiségi adatközlők névválasztási tendenciáját és tudatosságát tükrözi. A kérdőívben a házasságkötés helyére, idejére és az aktuális lakóhelyre, valamint az iskolai végzettségre vonatkozó kontrolladatok mellett a következő kérdéseket tettem fel:

1. Mi volt a születési neve és milyen házassági nevet (asszonynevet) választott?

2. Miért ezt a házassági nevet választotta? (Kik és/vagy milyen okok befolyásolták a döntését?)

3. Ma is ezt a nevet választaná-e? Miért igen/nem?

4. Ha lett volna törvény adta lehetőség rá, választott volna más nevet a házasságkötéskor?

5. A gyerekeik milyen családnevet kaptak/fognak kapni? (Kinek a családnevét kapják?)

+1 . Megváltoztatta-e a férje is a nevét a házasságkötéskor?

FERCSIK 2013-as megállapítását, miszerint a házasságban élő nők legtöbbje fontosnak tartotta/tartja, hogy családi állapotának megváltozását névviselésével is jelezze, az általam vizsgált adatok is megerösítik, habár jelentős a korpuszban azoknak a száma is, akik nem változtatták meg a nevüket házasságkötéskor. Ennek hátterére az NT/1 típus ismertetésénél térek ki. FERCSIK az országos statisztikai adatok vizsgálatával kimutatta, hogy az 1996-2003 közti korszakban mindössze a nők 4\%-a nem módosított nevet a házasságkötéskor (FERCSIK 2013: 376). 
1. táblázat: A vizsgált 70 névadat típus szerinti megoszlása a korpuszban

\begin{tabular}{|l|r|r|}
\hline \multicolumn{1}{|c|}{ Névtípus } & Nevek száma (db) & Nevek aránya (\%) \\
\hline T/1a: Rákóczi Ferencné & 3 & 4,3 \\
\hline T/2b: Rákóczi Ferencné Zrinyi Ilona & 0 & 0 \\
\hline T/2: Rákócziné Zrínyi Ilona & 22 & 31,5 \\
\hline NT/1: Zrínyi Ilona & 18 & 25,7 \\
\hline NT/2: Rákóczi Ilona & 8 & 11,4 \\
\hline KT/1: Zrínyi-Rákóczi Ilona & 19 & 27,1 \\
\hline KT/2: Rákóczi-Zrínyi Ilona & 0 & 0 \\
\hline
\end{tabular}

A mintavétel ugyan nem reprezentatív, de a korpuszban megjelenő névtípusok aránya jól jelzi azt, amit FERCSIK korábban, a 2004-2009 közötti országos statisztikák vizsgálatának fényében már megjósolt: a kevésbé tipikusnak tekintett kötőjeles nevek aránya az elmúlt években ugrásszerüen - a vizsgált hat évben több mint tízszeresére - nőtt (FERCSIK 2013: 377). Megfigyelésem szerint a nagyvárosi értelmiségi adatközlök körében ez a szám kiemelkedő, mintámban nagyjából minden harmadik házasságra lépő nő ezt a megoldást választotta. A kötőjeles házassági névhasználatot a 2004. január 1-jét követően házasságot kötők automatikusan kérhették, nem kellett külön névváltoztatási eljárást indítaniuk, mint korábban azoknak, akik így szerették volna kifejezni összetartozásukat (FARKAS 2003: 136). Míg 2004-ben az összlakosság házassági névviselését figyelembe véve mindössze 0,1\%-os volt a névtípus részesedése az országos adatokból, addig 2009-ben ez a szám már $1,3 \%$, ami - figyelembe véve az éves házasságkötések számát - a névtípus népszerüségének ugrásszerü növekedését mutatja (FERCSIK 2013: 377). Nem látszik beigazolódni RÉvÉSz KATALINnak még a törvénymódosítás elötti vélekedése, miszerint „a nagy tendenciák azt mutatják, ez a forma nem tehet szert valódi népszerüségre. A fejlődés ugyanis az egyre rövidebb névalakok preferenciájának irányába mutat." (RÉvész 2001: 70.) Megállapítása annyiból helytálló, hogy egyes adatközlők szerint a név hosszúsága kellemetlen ugyan, de többletet fejezhetnek ki vele, ezért megéri nekik a hosszabb névváltozat használata. Az egyik adatközlői vélekedés is erről szól: „Amikor egyik ismerösömmel beszéltem erről a témáról, azt mondta, hogy jó is, mert ha az ember lánya megváltoztatja a nevét, akár az ember lányának házasság előtti énje is módosul... talán mintha egy mellékszereplővé, de mindenképpen valamelyest más emberré válna, mint korábban. Bár nem ez volt a szándékom a nevem megtartásával kapcsolatban, de lehet, hogy van benne valami." (NT/1_34.) ${ }^{1}$

3.1. Névtípusok és identitás. A motivációk alapján tehát három tipikus névválasztó típust különböztethetünk meg: a hagyományőrzőt, az individuálist és a kompromisszumost. FERCSIK csoportosítását a motivációs tényezők mentén a következőképpen módosítottam:

${ }^{1}$ A továbbiakban az adatközlőktől való idézetek végén, zárójelben tüntetem fel az adatközlő azonosítóját. Ez az általa választott névtípust jelölő betükódból és az adatközlői sorszámból áll. (Például az NT/1_34 jelentése: „nem tipikus” házassági név/1, azaz a Zrínyi Ilona típus, 34-es adatközlő.) Az idézetekben megtartom az eredeti helyesírást, csak a nyelvi elemeket emelem ki kurzívval. 
3.1.1. Hagyományőrző névtípusok. Azon a képzeletbeli skálán, amelyről már korábban írtam, a T/1a típus a leginkább hagyományőrző. A T/1b-ben már megjelenik a születési név is, tehát ez már jóval kompromisszumkeresőbb típusnak tekinthető, ugyanakkor a -né megőrzése, jelenléte miatt alapvetően továbbra is a tipikus és hagyományőrző kategóriában maradunk. (Megjegyzendő, hogy a gyüjtött anyagban egyetlen asszony sem viseli a T/1b típusú nevet.) A legkompromisszumosabbnak a T/2 típust tekinthetjük, a skála középpontjában elhelyezkedve, hiszen ebben teljesül a hagyományőrzés kívánalma: megjelenik benne a -né asszonynévképző, ugyanakkor csak egy rövid névalakban, a férjezettséget egyértelműen kifejezve, de a születési nevet is egyben tartva. Sokaknak a -né forma ellen azonban az volt a legfőbb kifogásuk, hogy mivel az anyósuk már Rákócziné, nem szeretnék ugyanazt a nevet viselni, mint ő. FARKAS TAMÁs (2020: 150) kutatásai is alátámasztják az előbbi megállapítást, hiszen az asszonynév-változtatások indokai közt fontos szerepet játszik a névazonosság kiküszöbölésének szándéka (így az anyóssal megegyező néven való szereplés elkerülése is).

3.1.2. Kompromisszumos típusok. A fentiek alapján motivációs szempontból a T/1b és a T/2 típus is kompromisszumos, sőt a kevésbé tipikus (KT/1 és KT/2) típus képviselői is idetartoznak; ezeknél erősebb az újítási vágy, mint a hagyománykövetés. A kötőjeles házassági nevet választók a nevük megváltoztatásával is jelezni kívánják valamilyen formában családi állapotuk megváltozását, de a -né képzős megoldástól különböző okoknál fogva idegenkednek. Így tehát a két családnevet egymás mellé rendelve (sok esetben deklaráltan is az egyenrangúság kifejezésének szándékával) alkotják meg az új nevüket, a házassági nevet. Érdekességképpen megjegyzendő, hogy bár az egyenrangúság kifejezése a cél, mégsem találkoztam egyetlen KT/2 típusú névvel sem, tehát a teljes korpusz valamennyi kötőjeles nevében a férj családneve szerepel elöl, s ezt követi kötőjellel hozzákapcsolva a feleség családneve. Ez abból a szempontból persze logikusabb, hogy egyben tartja a feleség születési családnevét és utónevét, és jobban hasonlít arra a gyakorlatra, hogy ha a férj családneve vagy teljes neve + a -né képző megjelenik az asszonynévben, akkor megelözi a leánykori nevet.

3.1.3. Nem tipikus házassági nevek az önazonosság kifejezésének két végpontján. Egyfelől azok az adatközlők tartoznak ebbe a csoportba, akik - különböző okoknál fogva házassági névként megtartották születési nevüket (NT/1), vagyis nem tartották szükségesnek nevükkel is kifejezni házas voltukat, inkább korábbi nevük megőrzését tartották fontosnak az önazonosságuk kifejezéséhez. Másfelől azok tartoznak ide, akik éppen a szintén nem tipikus házassági név választásával (NT/2) annyira azonosulni kívántak férjükkel (és annak családjával), hogy a saját születési nevüket elhagyva, az új család (a férj) családnevét vették fel. Voltak, akik ezt a formát éppen azért kifogásolták, mert egyáltalán nem derül ki belöle a házas voltuk, illetve - ahogy az egyik adatközlö fogalmazott - ,nem testvére, hanem a felesége szerettem volna lenni a férjemnek” (KT/1_55). (Megjegyzendő, hogy bizonyos értelemben a leginkább hagyományörző T/1a típusra is a végletesség jellemzö, hiszen a Rákóczi Ferencné névtípusból valóban semmi nem derül ki a feleség saját nevéről, utónevéről.)

Alább részletesen bemutatom az egyes névtípusok szerinti motivációs tendenciákat a tipikus válaszkomponensek alapján (vö. Révész 2001). 


\subsection{Névtípusok és motivációk}

3.2.1. T/1a: Rákóczi Ferencné. Az összlakosságot figyelembe vevő hivatalos statisztikák alapján a 2010-es évek Magyarországán még ez lehetett a leggyakoribb házassági névtípus (FERCSIK 2013: 376). A fiatalok, illetve az újraházasulók körében azonban egyre kisebb a népszerüsége, egyre kevesebben választják házassági névként, ezért megjósolható, hogy a jövőben egyre ritkábbá válik. A korpuszban mindössze három fő szerepel ezzel a névtípussal. A névtípus viselésének legnagyobb nehézsége, amelyet azok az adatközlök is alátámasztottak, akik ezt a házassági nevet választották, hogy mások, akik csak leírva látják a nevüket, nem tudják, hogyan szólítsák meg öket. Erről a problémáról többen is beszámoltak az adatközlők közül: „Ma a nevemen annyit változtatnék, hogy a keresztnevem lenne a férjem vezetékneve mellett, mert megszólításnál senki nem fog Zoltánné-nak hívni, a bemutatkozásnál nem hangzik el a keresztnevem [....]. Akkor nem választottam volna másik nevet, viszont a gyakorlati életben tapasztaltak alapján ma már igen.” (T/1a_1.) Úgy értesültem, hogy a fenti gondolatokat megfogalmazó adatközlő azóta hivatalosan is módosította a házassági nevét a Rákóczi Ilona típusra.

Egy másik (kompromisszumos névtípust választó) adatközlö pontosan a fenti adatközlői válaszban bemutatott, megszólítással kapcsolatos probléma miatt igyekezett elkerülni a T/1a névtípus választását, mivel édesanyja neve is ebbe a típusba tartozik, és nála már tapasztalta a megszólítással kapcsolatos problémákat: „A -né képzős családnév nekem elavult, az idősebb korosztályra jellemző, konzervatív gondolkodásmódot tükröz. Elrejti a nő valódi nevét, ráadásul a gyakorlatban sem túl praktikus, mert nehézkes a megszólítás. (Érdekességképpen: láttam olyat, hogy édesanyámat, akit Rákóczi Ferencné-nek hívnak, egy válaszlevélben így szólították meg: Kedves Ferencné! - kényszermegoldás, szerintem szörnyü!)" (KT/1_57.) Erre a nehézségre egyébiránt az asszonynév-változtatások indokai között is akadtak példák (FARKAS 2020: 151).

Ennek a problémának az orvoslására a névtípust viselő adatközlők azt javasolták válaszaikban, hogy jó volna egy olyan névváltozat is, amely csak a feleség utónevét kapcsolja hozzá a névtípushoz, ezzel egy háromtagú, informatív, nem túl hosszú, jól használható nevet eredményezve, példánknál maradva: Rákóczi Ferencné Ilona. Mindannyian így is mutatkoznak be. Ketten az egészségügyben dolgoznak, és csak az utónevüket írják fel a névtáblájukra, a házassági nevük után.

Ezzel ha nem is tudatosan, de egy igen régi névhasználati mintát követnek, amelyet Szabó T. AттіLA a magyar asszonynevek kialakulásának, használatának, elterjedtségének vizsgálatával kapcsolatosan mutat be: „Nagyon gyakori, főként a XVI-XVII. században az is, hogy a férj nevével alakított asszonynév mellett használják a feleség puszta keresztnevét is; így: 1570: »Zekely Matthene Martha azzon«. 1573: »Katalin azony Takats Andrasne«. A jobbágyasszonyok esetében »Kovács Jánosné Anna«" (SzABó T. 1970: 50).

Feltehetjük a kérdést, hogy akkor ennyi nehézség és kritika ellenére miért választotta mégis ezt a névtípust a három adatközlö? Azért, mert mindannyian a teljes elkötelezettséget, a férjükhöz való tartozást szerették volna kifejezni a választásukkal. A következő idézet arra is rávilágít, hogy milyen sztereotípiák dolgoznak bennünk. Ilyen például, hogy az idősebb korosztály (az 1974 előtt házasodottak) névviselésére jellemző(bb) ennek a típusnak a használata, és bizonyos „karrierpozíciókban” nem tanácsos, „,nem megengedhető”, társadalmilag nem támogatott ennek a névtípusnak a választása, hiszen viselőjét nem tekintik 
elég modern gondolkodásúnak, versenyképesnek stb. „Szerintem az a legszebb, hogy mikor két ember örökre összetartozik, a nevük is majdnem teljesen azonos, és így az én nevemben benne van a férjemé. A házasságunkat gondoltam annyira komolyan, hogy fölvállaljam az ő nevét is, akárcsak őt magát. Emellett szeretem a hagyományokat is: a mi családunkban mindenki így használta az asszonynevét. Ennek ellenére, a férjemen kívül mindenki próbált erről lebeszélni, hogy a »mai világban...«, »hogy lehet majd szólítani...«, »csak a bonyodalom van vele...«, »majd úgyis vissza kell venni...«, »elveszíted önmagad..« Én úgy gondolom, olyan szakmám van (gyógyszerész), ahol úgy viselhetem a nevem, ahogy akarom, mert nem jelent hátrányt a klasszikus asszonynév, természetesen, ha marketing vezető lennék egy multi cégnél, nem tehetném meg, hogy fiatalként így hívjanak. (Hozzáteszem, az egészségügyi tevékenység során használt nevem is ez, pedig megtehetném, hogy az a lánykori legyen, míg a személyi igazolványomban a jelenlegi asszonynevem áll.) Bemutatkozni úgy szoktam, hogy Rákóczi Ferencné Ilona - ugyanúgy háromtagú, mintha bármelyik más módon vettem volna föl a nevem. Az ismerősök Iloná-znak, hogy mit írok alá, az meg olyan mindegy másnak :).... A lánykoromnak vége, a lánykori nevemhez nem ragaszkodtam. Nem sajnálom, mert nem különösebben zengzetes (pl. Sziklaváry), és mert nem csúnya a férjem neve sem (pl. Tar). Az sem zavar, hogy vicces, mikor a nevemen hívnak be valahová, meglepődnek, hogy nem egy hatvanéves nénike tipeg oda :)... És nem is tartanak bogarasnak, mikor megindoklom, miért hívnak így..." (T/1a_2.)

A másik két asszony azért is döntött amellett, hogy semmilyen formában nem örzi meg korábbi nevét, mert nem volt jó a kapcsolata az édesapjával, akinek a nevét viselte, ezért sem tartotta fontosnak az apai név továbbvitelét: ,azért választottam ezt a házassági nevet, mert számomra teljes elkötelezettséget, odaadást jelent, ha átveszem a férjem nevét teljes egészében, illetve nem volt felhőtlen a kapcsolatom apukámmal, ezért a nevemet sem szerettem, saját döntés volt" (T/1a_1).

Mint azt alább is láthatjuk majd, az anyai minta követése a névválasztásnál, illetve az édesapa szerepe a születési (család)név megőrzésében vagy elhagyásában számos adatközlőnél hivatkozási alap. Így a kompromisszumos névtípusoknál voltak olyan adatközlők, akik éppen azt emelték ki, hogy az édesapjuk nem szólt bele, de örült, hogy valamilyen formában megtartották az ő nevét is. Mint ahogy például az alábbi adatközlő édesapja is: „Mindenképp jelezni szerettem volna a nevemmel az összetartozásunkat, a lánykori nevemet szeretem, meg szerintem Apukám is örült neki, hogy az is megmaradt” (KT/1_52).

3.2.2. T/1b: Rákóczi Ferencné Zrínyi Ilona. Nincs erre a névtípusra példa a korpuszban. A T/2 típust választók közül volt, aki gondolkodott ugyan rajta, de végül a névforma hosszúsága miatt nem választotta.

3.2.3. T/2: Rákócziné Zrínyi Ilona. Ezt az igazán kompromisszumos névtípust választó adatközlők mindannyian büszkék férjezett állapotukra, és fontosnak tartják, hogy ezt névhasználatuk is tükrözze a kívülállók felé. A férjjel való összetartozás hagyományos kifejezése is ott van szinte minden válaszkomponensben. Sokan azt is megindokolják, hogy miért nem a kötőjeles névformát választották. A válaszokból, illetve a teljes korpuszból is kiderül, hogy a napjainkban férjhez menök körében ez a két házassági névforma (T/2 és KT/1) verseng egymással. A hagyományőrzés kontra újítás („,modernebbül, másképp mint anyáink") és az összetartozás kifejezésének, a férjnek, a gyermekeknek, azaz a családnak a 
„közös” névviselése jegyében való két választási lehetőség verseng egymással, mint az az alábbi idézetekből is kiderül:

„Névválasztásomban szerettem volna a férjemmel való összetartozásunkat is szimbolizálni. A családunkban hagyományosnak tekinthető a »né«. Viszont szerettem volna azt is, hogy ha valaki hallja vagy elolvassa a nevemet találkozzon a keresztnevemmel is." (T/2 12.)

„A Rákóczi Iloná-n gondolkodtam még, hogy rövidebb legyen, de akkor bemutatkozásnál az új ismerőseim nem tudnák, hogy házas vagyok, és ez nekem fontos:) Úgyhogy maradt a Rákócziné." (T/2_11.)

„Teljes nevet nem akartam felvenni (elavultnak és személytelennek tartom), ha pedig csak a sajátomat használom, az nem fejezi ki az összetartozásunkat [...] a kötőjeles verzió furcsán hangzott volna" (T/2_8).

Több adatközlő is hangsúlyozza a mintakövetést, a családban bevett névviselési formák megörzésének szándékát. A következő megnyilatkozásban is erről van szó: „Konzervatív családból származom, eszembe sem jutott, hogy ne vegyem fel férjem nevét. Mindenképp -né-s variációt szerettem volna, hogy látszódjon, hogy férjnél vagyok és mi az ő neve. A kötőjeles nekem pont ezért nem tetszik, mert ott nem derül ki, honnan jön a név, lehet akár a születési név is kötőjeles. Aztán szempont volt, hogy a keresztnevem megmaradjon, hogy a bemutatkozáskor mondhassam a hivatalos nevem és akkor is tudják, hogy szólíthatnak. Ezek után két lehetőség maradt, a másik iszonyú hosszú lett volna. Bár rám lett bízva a döntés, a férjem örült a választásnak, szerintem csalódott volna, ha nem veszem fel a nevét, bár ez fel sem merült." (T/2_18.)

A családi hagyományok folytatására utal az alábbi idézet megszólalója is: „Azért választottam ezt a házassági nevet, mert szerettem volna, ha »látszik, hallatszik« a nevemen, hogy házasságban élek. Egyrészt a férjemhez való tartozást szerettem volna kifejezni, másrészröl a házasságban élő ember státusát az élet következő, fontos lépcsőfokának tekintem, és az esküvőkor erre rendkívül büszke voltam. A kötőjeles megoldást is el tudtam volna képzelni, de [...] nagyon szokatlan hangzású volt nekem. (Szerintem itt nagyon meghatározó a gyermekkorban, fiatal felnőttkorban tapasztalt névminta.)” (T/2_15.)

A fenti adatközlő azzal folytatja gondolatmenetét, hogy ma már talán nem a -né-s forma mellett döntene: „Nem biztos, hogy ezt választanám. Lassan hozzászokik a fülem a két családnév + keresztnév formához, és az sem igaz, hogy az ilyen nevü hölgyekröl nem tudni, hogy férjezettek-e. Az esetek többségében szerintem úgy sejthető, hogy férjnél vannak." (T/2_15.)

Két adatközlő (T/2_13; T/2_17) is elmondta, hogy ha lehetősége lett volna rá, akkor a házasságkötéskor a férje nevét -né képző, illetve kötőjel nélkül vette volna fel a saját születési neve elé, s ha lenne ilyen házassági névtípus, ezt kérelmezné: Rákóczi Zrínyi Ilona. Erről az egyikük így nyilatkozik: „Szerettem volna, ha az én nevemben is benne van a leendő gyerekeim neve, de a sajátomat sem akartam teljesen feladni, az az enyém. Szerettem volna simán 3 nevü lenni, [...] még dallamos is, de a kötőjelet nem tudtam elfogadni, pláne, hogy nagyon sok digitális rendszerben gondot okoz és nagyon bénának éreztem, ezért végül a -né-s alakot választottam. De még mindig szívesen lennék csak simán 3 nevü, minden nélkül.” (T/2_13.)

3.2.4. NT/1: Zrínyi Ilona. A történeti adatok vizsgálatával kimutatható, hogy „egészen általános volt a régiségben, hogy a feleség a házasságban megtartotta leánynevét, 
legfeljebb az e névhez ragasztott asszony jelölhette esetleg a szóban forgó fehérszemély feleség voltát. [...] Pl. 1551: » Pogan Soffya azzon«. 1569 »Myhalfy Barbara asszony« (Szabó T. 1970: 50).

Az 1996-2003 közötti országos statisztikai adatok vizsgálatával FercsiK ERzséBET (2013: 376) kimutatta, hogy ebben az időszakban a nők 4\%-a nem módosított nevet a házasságkötéskor. A születési nevüket megtartók közül a legtöbben arra is hivatkoznak, hogy ez a döntés a férjüknek is tetszett, ő is egyetértett velük. Ezek az adatközlők - hasonlóan a KT típust választókhoz - a -né formát általában elavultnak tartják, valamilyen oknál fogva idegenkednek tőle (pl. öregesnek érzik, az édesanyjuk korosztályára jellemző névviselési formának; nem szeretnék majdnem ugyanazt a nevet viselni, mint az anyósuk stb.), vagy büszkék a saját családnevükre, őseikre; esetleg ritkább családnevet viselnek, mint a férjük, ezért szeretnék megtartani. Az általam végzett vizsgálatban majdnem egyharmad részben tartották meg az adatközlők a születési nevüket házassági névként is. Ennek oka az lehet, hogy a mintában kiugróan magas számban szerepelnek olyan adatközlök, akik már házasságkötésük elött elértek bizonyos szakmai sikereket (pl. publikáltak, verseskötetet jelentettek meg, praktizálni kezdtek stb.). Mivel ezek a születési nevükhöz köthetők, nem szerettek volna nevet módosítani. A következö adatközlői megnyilatkozások is ezeket az okokat említik:

„A férjem elavult gesztusnak tartotta volna, hogy felvegyem a nevét. Plusz addigra megjelent 2 könyvem a lánykori nevemen, zavart okozott volna a váltás.” (NT/1_28.)

„Szeretem a vezetéknevem, jobb mint a férjemé, és büszke vagyok azokra akik elöttem viselték. Ma is ezt választanám.” (NT/1_29.)

„Szeretem a nevem, szakmám miatt egyszerübbnek tủnt” (NT/1_35).

„Több okom is van, de fontossági sorrendet nem igazán tudok felállítani közöttük: A) Szeretem a nevemet (részben azért, mert elég egyszerü, például ékezetek sincsenek benne), és ugyan nem vagyok nagyon híres, de publikáltam már ezt-azt ezen a néven. B) Az én nevem kevésbé gyakori, mint a férjemé [...]. C) Anyukám is megmaradt a lánykori nevénél. D) Kötőjellel hülyén hangzott volna, -né képzős nevet meg nem akartam, mert akkor biztosan »Rákócziné « lettem volna, amelyet nem éreztem volna a magaménak, és amúgy is van már olyan a családban. :-)" (NT/1_36.)

„Ezt a nevet apukámtól kaptam, nem cserélném semmire:) A férjem nem igényelte. Sőt, talán még imponált is neki, hogy ilyen »autonóm« vagyok! Ö sem veszi fel az enyémet, ez így kvitt:) 28 évig jó volt, eztán sem kell nekem másik. Az ő nevében van ékezet, két betüvel jelzett mássalhangzó, külföldön szerintem problémásabb.” (NT/1 32.)

Azok, akik megőrzik születési (leánykori) nevüket a házasságukban, formailag ugyan nem változatnak a nevükön, de névjogi szempontból megváltozik a név funkciója: ez is házassági névvé lesz (FARKAS 2003: 133). Több adatközlő is félig tréfálkozva jegyezte meg, hogy az adminisztratív nehézségeket, a papírcserével járó ügyintézést szerette volna elkerülni, és ezért nem változtatott nevet, így hivatalos papírok kitöltésekor a születési nevét kell még egyszer feltüntetnie a házassági neve rovatban, hiszen a kettő formailag ugyanaz: „Főként a praktikus oldalát tekintettem: nem kell hosszú sorokat végigvárni az okmányirodában az adatok lecserélése miatt, és azon gondolkozni, hogy hol kell még szólnom..." (NT/1_34.)

3.2.5. NT/2: Rákóczi Ilona. Az e névtípust választók elsősorban azt szerették volna, hogy teljesen azonos legyen a családnevük a férjükkel, gyermekeikkel; azaz egy ún. „közös családi név” megkonstruálása volt a céljuk, ahogy az alábbi adatközlő is vallja: 
„Mindenképpen fel akartam venni a férjem nevét. Most már mi vagyunk elsősorban egy család, ezt jeleníti meg a közös családi név. Ez egy fontos cezúra az életben. Fontos volt még az egyszerüség (ezért nem választottam a -né ill. a háromneves alakot), és a külföldi használhatóság, érthetöség is." (NT/2 46.)

Egy másik nyilatkozó szintén emellett érvel: „A férjem nevét mindenképpen fel akartam venni, a -né-s változatot nem akartam választani, a Rákóczi-Zrínyi túl sok lett volna. A leánykori nevemtől azért is tudtam búcsút venni, mert abban az időben különösen rossz volt a kapcsolatom az apai rokonaimmal. Ráadásul nem teljesen búcsúztam el a régi nevemtől sem, hiszen születési névként és a gyermekem anyjaként mindenhol megjelenik. Az aktív e-mail címem is maradt [...]. Rákóczi Ilona-ként új embernek éreztem magam, és büszke voltam/ vagyok rá, hogy a férjemtöl kaptam a nevet. Emellett könnyebb kimondani is.” (NT/2_45.)

Akiknek a legkevésbé tetszett ez a névforma, azoknak két fö ellenérvük volt: 1. névhasználatában nem a férje testvérének (vagy gyermekének), hanem a feleségének szeretne látszani (KT/1_55); 2. ez a névforma idegen csengésü, külföldi mintát követ. Ehhez a második ellenérvhez annyi megjegyzést érdemes füzni, hogy a szóbeliségben, a népnyelvben a Rákóczi Ilona típus már jóval korábban megjelent, például ha a férjet ismerték, s a távolabbról jövő feleséget így azonosították vele. (Vö. még ÖRDÖG 1975: 69-72, FARKAs 2003: 134-135.) Az egyik adatközlő azt is megjegyzi, hogy ma Erdélyben is így kapnak nevet az asszonyok (vö. B. Gergely 1977, 1995: 186-191), ezért ő családi mintakövetésként mutatja be a névválasztását. Ehhez azonban annyit érdemes hozzátenni, hogy a román adminisztrációban elvárt névforma nem a magyar ragadványnevek használati körét veszi figyelembe, hanem a magyar névrendszertől valójában teljesen idegen, francia mintát tükrözi (SzABó T. 1970: 51). Az egyik, Erdélyből származó adatközlö is az erdélyi, anyai minta miatt vette fel férje családnevét: „Erdélyben az asszonyok ebben a formában veszik fel a nevüket, ezt az anyai családi ágat akartam erösíteni. Ez érzelmi döntés volt inkább, sem mint tudatosan végiggondolt." (NT/2_44.)

3.2.6. KT/1: Rákóczi-Zrínyi Ilona. Az összetartozás kifejezését, a felek egyenrangúságát és régi „önmaguk”, önazonosságuk megőrzését is hangsúlyozzák, akik ezt a névtípust választják. Az összetartozás kifejezésének a szándéka mellett „maibbnak”, modernnek érzik ezt a formát, ugyanakkor a régi, kötőjeles családnevek eleganciájából is megőrzött valamit szerintük. Ebből is fakadhat a népszerüsége, divatja. Az azóta eltelt idő és a névtípus népszerüsége egyértelmüen igazolta FARKAS TAMÁs 2003-as vélekedését: „E névtípus hazai megjelenésében bizonyára a külföldi minták is szerepet játszottak, s talán nem szabad számításon kívül hagynunk azt a presztízst sem, amellyel a kettős családnevek a magyar társadalomban - többféle okra visszavezethetően - rendelkeznek. Ez a házassági névtípus azonban a házas felek összetartozásának és egyenjogúságának kifejezésére alkalmas lehetőségnek tünik, s több más házassági névformánál informatívabb, azaz praktikusabb is. Mindez pedig önmagában is felkelthette, illetve felkeltheti az igényt iránta." (FARKAS 2003: 139.) Az összetartozás és az egyenrangúság kifejezésének szándékát hangsúlyozzák az alábbi adatközlöi vélekedések is:

„Az összetartozást szerettem volna kifejezni. Ez a verzió szerintem a felek egyenrangúságát is jelzi.” (KT/1_54.)

„[...] ha csak az övét tartom meg akkor az olyan, mintha a testvére lennék, és továbbra sem akartam úgymond feladni magam, ezért maradt a kötőjeles megoldás, ami összetartozást és egyenrangúságot szimbolizál szerintem.” (KT/1_55.) 
„Saját vezetéknevem jobban tetszik, de szimbolizálni akartam az összetartozást e módon is. A -né formát elavultnak tartottam." (KT/1_53.)

,[...] meg akartam maradni kicsit önmagam is.” (KT/1_60.)

Az egyik adatközlő szinte az összes lehetséges névformán végigvitte az érvrendszerét, hogy bemutassa, végül miért a kötőjeles megoldást választotta. Ma már azonban nem biztos, hogy így döntene: „A Rákócziné formát nem szeretem. Öreges, elcsépelt. A Rákóczi Ferencné teljes identitásvesztés. Mindenképp ki akartam fejezni a változást, összetartozást, ezért vettem fel a nevét. Bár a saját vezetéknevemet nem igazán szeretem, mégis úgy döntöttem, hogy nem hagyom el. Most lehet, hogy a Rákóczi Iloná-t választanám.”(KT/1_51.)

3.2.7. KT/2: Zrínyi-Rákóczi Ilona. Mivel az adatközlőknek az esetek többségében a születési név egyben tartása is céljuk volt, KT/2 típus nincs a mintában. Egyetlen adatközlö nyilatkozott úgy, hogy jobban szerette volna a férje nevét a kötőjel után, a második helyre tenni, de az nem hangzott volna jól.

4. Röviden a férjek és a gyermekek névviseléséről. Az adatközlőknek nincs a házasságkötéskor új (házassági) nevet választó férjük, de vannak „kötőjeles nevü gyerekeik”, akik nemcsak az édesapjuk, hanem az édesanyjuk nevét is megkapták.

A férjek névviselésével kapcsolatban egyértelmüen hagyományőrzőnek tekinthető valamennyi adatközlői válasz. A „Megváltoztatta-e a férje is a nevét a házasságkötéskor?” kérdésre az adatközlők nagy része beérte az egyszerü „nem” válasszal, de volt olyan, aki hozzátette, hogy „fel sem merült" vagy „dehogy”, ami öszinte megdöbbenést fejez ki a kérdésfeltevéssel kapcsolatban.

A válaszadók gyermekeinek családnévadása is jellemzően a konzervatívabb mintát követi, ti. az apa családnevét kapták. Az egyik válasz szerint „ebből a szempontból régimódiak vagyunk, fel se merült más lehetőség” (T/2_4). Két kivétellel minden adatközlő úgy nyilatkozott, hogy gyermekeik az apa nevét kapták (vagy fogják kapni). A két eltérö esetben a gyermekek kötőjelesen viselik az anyjuk születési családnevét is az apa családnevével együtt: a kötőjeles név első tagja az apa családneve, a második tag az anya családneve. Ezt a megoldást mindkét családban azért választották, mert az anyának csak leánytestvérei vannak, így családnevüket nem vinné tovább senki. A törvény adta lehetőségek közül ezt a névválasztást elsősorban a hagyományőrzés, nem az újító szándék motiválja.

5. Összegzés, kitekintés. Mint fentebb láthattuk, a jelenlegi diskurzus két fö, ellentétesen ható mozgatórugója, irányítója a házastárs családnevének teljes vagy bizonyos fokú átvétele, s ezzel az új családhoz tartozás, a férjjel és gyermekekkel való azonosulás szándéka szemben a saját születési név megtartásával, s vele az individualitás kifejezésével. A házassági nevek gazdag kínálata, megválaszthatóságának alakulása jól tükrözi a mindenkori társadalmi igényeket, és használatának jogi szabályozása igyekszik is követni azokat, ahogy erre FARKAS TAMÁs (2003: 141-142) is utalt már korábban.

A házassági nevek jogi szabályozásával kapcsolatban az egyik adatközlő találóan így jellemezte az aktuális helyzetet: „nem tudom milyen más lehetőség lenne még, szerintem a törvény most lefedi az összes lehetséges permutációt" (KT/1_55). Mindössze két adatközlö fogalmazott meg egy-egy - a törvény által ma még nem biztosított - újabb névviselési lehetőséget. A meglévő kínálat mellé szívesen látnának két további típusú, három névelemből álló alakot, melyek az alábbiak lennének. 
A T/1a típus viselöi nem hivatalosan a következőképpen használják nevüket, s ha volna törvény adta lehetőség, akkor ketten hivatalossá is tennék a férj családneve + keresztneve -né képzővel + a feleség keresztneve formát (Rákóczi Ferencné Ilona), amely - mint a történeti példaanyagon láttuk - igen hosszú ideje létezik a szóbeliségben, a nem hivatalos magyar asszonynévhasználatban. Érdekességként megjegyezném, hogy az OTP Bank egyik, vállalkozói hiteleket népszerüsítő plakátján a Jármitészta tulajdonosai a következő névvel szerepelnek: Járminé Borika és Jármi Tivadar. Egészen biztos, hogy a páros női tagjának a neve nem így szerepel a személyi igazolványában, hiszen ez a névváltozat nincs a hivatalosan anyakönyvezhető névtípusok között. A plakát jól tükrözi azt a társadalmi igényt, hogy az asszony „hivatalos nevének” valamely névformája azért szerepeljen a reklámban: ezzel kifejezik férjes állapotát, férjével való összetartozását, ugyanakkor a keresztneve vagy beceneve feltüntetésével személyesebbé teszik a marketingüzenetet. ${ }^{2}$

A másik újító ötlettel a T/2 típust választók közül ketten álltak elö: a Rákóczi Zrínyi Ilona (kötőjel és -né nélküli) alakot részesítenék előnyben. A szóbeliségben ez szintén jelenlévő alak, hiszen szóban „nem tesszük ki” a kötőjelet, így tulajdonképpen minden kötőjeles név így hangzik a bemutatkozáskor. Házassági névként azonban azért lehet problematikus a kötőjel nélküli névalakok használata, mert bizonyos személynévi eredetủ családneveknél zavart okozhat a három elem egymás utáni használata (pl. Kis Márta Anna, ahol a Márta névelem lehet családnév és keresztnév is). Érdekességképpen megjegyzendő, hogy a családnév kezdőbetüvel és ponttal való rövidítésének (pl. R. Zrínyi Ilona) hivatalossá tétele, melynek használata gyakori például a tudományos életben, ezúttal nem merült fel az adatközlői válaszok között.

Hogy szükséges-e a jövőben újabb változatok bevezetése, valóban mutatkozik-e szélesebb körü társadalmi igény a fent bemutatott névalakok törvényesen választhatóvá tételére, ezek mérlegelése a korábbi jogalkotási gyakorlatban is sikerrel alkalmazott társadalmi igényfelmérés és szakmai véleményezés után a jogalkotók feladata.

\section{Hivatkozott irodalom}

Baranyiné Kóczy Judit 2020. Asszonynév, család és identitás összefüggései a XXI. század elején. In: Fóris Ágota - Bölcskei Andrea - Heltai JÁnos Imre szerk., Nyelv, kultúra, identitás. Alkalmazott nyelvészeti kutatások a 21. századi információs térben. IV. Szociolingvisztika, névtan, nyelvtörténet. A MANYE Kongresszusok Előadásai 12/4. Akadémiai Kiadó, Budapest. 39-46. https://doi.org/10.1556/9789634545385

Csepeli György 1997. Szociálpszichológia. Osiris Kiadó, Budapest.

FARKAS TAMÁs 2001. A magyar hivatalos család-és asszonynév-változtatások (különös tekintettel a 20. század második felére). Doktori (PhD) értekezés. ELTE BTK, Budapest.

FARKAS TAMÁs 2003. A házassági névviselés új szabályozásához. Magyar Nyelvjárások 41: 133-142. FARKAS TAMÁs 2020. Asszonynévhasználat és asszonynév-változtatás a 20. század második felében. Névtani Értesitö 42: 143-164. https://doi.org/10.29178/NevtErt.2020.8

FercsiK Erzsébet 2002. A házas nők névviselése a XX. század utolsó éveiben - öt év statisztikáinak tükrében. Névtani Értesítö 24: 99-107.

${ }^{2}$ A plakát elérhető volt a következö honlapon: https://www.otpbank.hu/portal/hu/MKV (2018. 01. 04.) 
FERCSIK ERZSÉBET 2008. A női nevek kutatása a magyar névtudományban (1958-2007). In: BöLCSKEI Andrea - N. Császi Ildikó szerk. Név és valóság. A VI. Magyar Névtudományi Konferencia előadásai (Balatonszárszó, 2007. június 22-24.). A Károli Gáspár Református Egyetem Magyar Nyelvtudományi Tanszékének Kiadványai 1. Károli Gáspár Református Egyetem Magyar Nyelvtudományi Tanszéke, Budapest. 342-349.

Fercsik Erzsébet 2012a. Házassági név és identitás. A házas nők önjelölő névhasználata egy internetes közösségi oldalon. In: BALÁzs GÉZA - VeszElszKi ÁGNes szerk., Nyelv és kultúra. Kulturális nyelvészet. Magyar Szemiotikai Tanulmányok 25-26. Inter Kultúra-, Nyelv- és Médiakutató Központ Kht. - Magyar Szemiotikai Társaság - PRAE.HU Kft. - Palimpszeszt Kulturális Alapítvány, Budapest. 314-318.

Fercsik Erzsébet 2012b. The Legal Regulation of Married Use and Its Practice in Hungary. Onoma 47: 57-80. https://doi.org/10.2143/ONO.47.0.3085139

FercsiK ERzséBet 2013. A házassági névválasztás trendjei. In: Tóth Szerges szerk., Társadalmi változások - Nyelvi változások. Alkalmazott nyelvészeti kutatások a Kárpát-medencében. A XII. MANYE kongresszus elöadásai. Szeged, 2012. április 12-14. A MANYE Kongresszusok előadásai 9. MANYE - Szegedi Egyetemi Kiadó Juhász Gyula Felsőoktatási Kiadó, Budapest-Szeged. 375-379.

B. Gergely Piroska 1977. A kalotaszegi magyar ragadványnevek rendszere. Kriterion Kiadó, Bukarest.

B. Gergely Piroska 1995. Mesterségüző asszonyemberek megnevezései az erdélyi régiségben. Magyar Nyelv 91: 186-191.

LaczKó Krisztina 2008. Asszonynévhasználat Budapesten, 1974-2006. In: Bölcskei ANdrea N. Császi Ildikó szerk., Név és valóság. A VI. Magyar Névtudományi Konferencia elöadásai (Balatonszárszó, 2007. június 22-24.). A Károli Gáspár Református Egyetem Magyar Nyelvtudományi Tanszékének Kiadványai 1. Károli Gáspár Református Egyetem Magyar Nyelvtudományi Tanszéke, Budapest. 406-412.

Ördög Ferenc 1975. Az asszonyok megnevezése a népnyelvben. In: SzATHMÁRI István - ÖrdöG Ferenc szerk., Pais Dezső tudományos emlékülés Zalaegerszegen. A Magyar Nyelvtudományi Társaság Kiadványai 140. Magyar Nyelvtudományi Társaság, Budapest. 69-72.

PataKi Ferenc 1982. Az én és a társadalmi azonosságtudat. Kossuth Kiadó, Budapest.

PÉntek János 2011. Nyelv és identitás a Kárpát-medencében. In: PÉnTeK János szerk., Változó korunk - változó nyelvünk. Komp-Press Kiadó, Kolozsvár. 31-49.

Ptk. = Új Polgári Törvénykönyv. https://net.jogtar.hu/jogszabaly?docid=a1300005.tv (2020. 12. 01.)

RAÁTz Judit 2004. Új névformákkal az Európai Unióba? Névtani Értesitő 26: 66-73.

RAÁTz Judit 2007. A nők névviselési szokásai Magyarországon és az EU-ban. In: BARÁt ERzséBet SÁNDOR KLÁra szerk., A nö helye a magyar nyelvhasználatban. „Nyelv, ideológia, média” konferencia, 2005. szeptember 8-9. JATEPress, Szeged. 169-177.

RÉvÉsz Katalin 2001. Asszonynevek a szentendrei névhasználat tükrében. Névtani Értesitö 23: $57-75$.

Szabó T. Attila 1970. A magyar asszonynév és - még valami. In: Uő, Anyanyelvünk életéböl. Válogatott tanulmányok, cikkek 1. Kriterion Könyvkiadó, Bukarest. 48-54.

SzILÁGYi-Kósa Anikó 2015. Mai személynevek kutatása. In: FARKAS TAMÁs - Slíz Mariann szerk., Magyar névkutatás a 21. század elején. Magyar Nyelvtudományi Társaság - ELTE Magyar Nyelvtudományi és Finnugor Intézet, Budapest. 145-164.

UGRóczKy MÁrIa 1997. Új magyar utónévkönyv. BM Kiadó, Budapest. 
Zelliger ERzséBet 2012. A magyar nyelv használata a felsö-ausztriai magyar diaszpóra körében. Magyar Nyelvtudományi Társaság, Budapest.

SZABÓ T. AnNAmÁRIA Ulla ORCID: https://orcid.org/0000-0002-4343-4920

ELTE Eötvös Loránd Tudományegyetem

Bölcsészettudományi Kar

\section{Annamária Ulla Szabó T., The use of married names in Hungary in the $21^{\text {st }}$ century}

This study presents a survey about motivations and tendencies in the choice of married names in Hungary conducted in 2017. Informants were married women between the age of twenty and forty, who were married after the last regulation of married names passed in 2004. All the seven possible official name types are listed and studied: A) the three traditional name types (with the -né suffix); B) the two-surname versions based on compromise: double-barrelled names with the two birth names; C) the two unusual or non-typical married names such as the woman's birth name or the woman's first name with the husband's family name. The paper illustrates how identity factors can influence the choice of a certain name type. The traditional name types, the two-name versions based on compromise, and unusual or non-typical names all have a different effect, because they express the individuality and the marital status of the married woman in different ways. The study presents the different opinions and interpretations of the married informants about the motivations of their name choice. This socio-onomastic research proves that the most popular married names contain the woman's birth name in some form as an expression of their individuality while also reflecting their changed marital status. 